Alma Mater Studiorum - Università di Bologna DEPARTMENT OF ECONOMICS

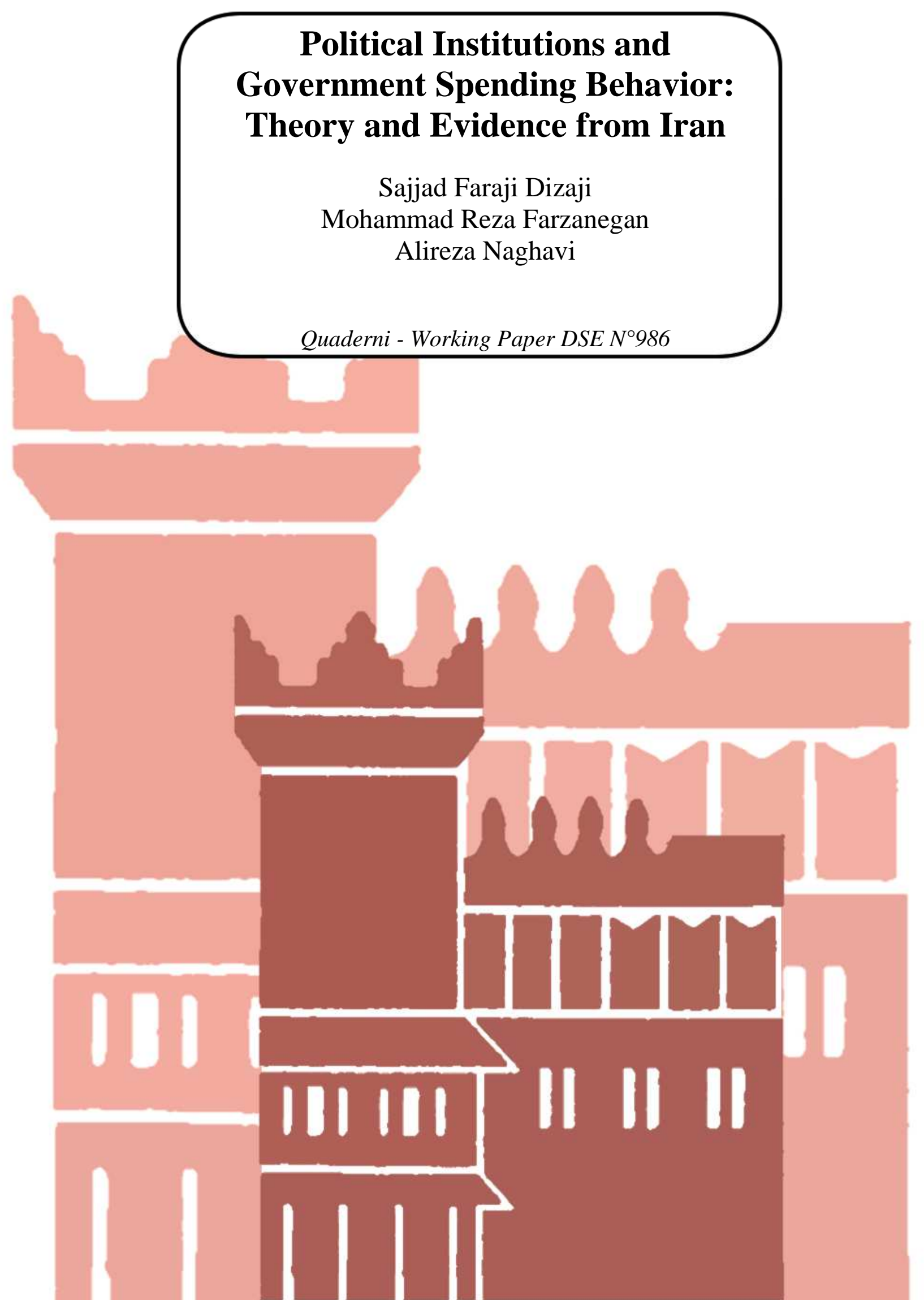




\title{
Political Institutions and Government Spending Behavior: Theory and Evidence from Iran
}

\author{
Sajjad Faraji DIZAJI \\ Tarbiat Modares University \\ Address: \\ Jalal Ale Ahmad Highway, P.O. Box: 14115-111, \\ Tehran, Iran \\ Email: $\underline{\text { s_dizaji@modares.ac.ir }}$
}

\begin{abstract}
Mohammad Reza FARZANEGAN
Philipps-University of Marburg, Center for Near and Middle Eastern Studies (CNMS), Marburg, Germany \& CESifo (Munich), MACIE (Marburg) and ERF (Cairo)
\end{abstract}

Address:

CNMS, Department of the Middle East Economics

Deutschhausstraße 12

35032 Marburg, Germany

Email: farzanegan@uni-marburg.de

Tel: +4964212824955

Fax: +4964212824829

Web: http://www.uni-marburg.de/cnms/wirtschaft

\section{Alireza NAGHAVI}

Department of Economics, University of Bologna

Address:

Piazza Scaravilli 2, 40126 Bologna, Italy.

Email: alireza.naghavi@unibo.it

Tel: +390512098873

Fax: +390512094080

Web: http://www2.dse.unibo.it/naghavi/ 


\title{
Political Institutions and Government Spending Behavior: Theory and Evidence from Iran
}

\begin{abstract}
This study examines how quality of political institutions affects the distribution of government budget in Iran. We first introduce a mechanism through which this can shift government expenditure from patronage to more constructive public spending. Using impulse response functions (IRF) and variance decomposition analysis (VDC) on the basis of Vector Autoregressive (VAR) model, our results imply that a positive shock towards more democratic institutions leads to negative and statistically significant response of military spending and positive and statistically significant response of education expenditures. Our results are robust to different political institutional quality indicators, ordering of variables in the VAR and different specifications of government spending categories.
\end{abstract}

JEL Classification: H11, H41, P16, O53, O43

Keywords: political institutions, military spending, Iran, VAR modelling 


\section{1- Introduction}

Literature and historical evidences show that dictators in oil rich economies depend on redistribution of oil rents and if it does not work they stick to repression policies, which need well-established military and security apparatus (Wintrobe 2001 and 2012; Acemoglu et al., 2010). While autocracies have been associated with negative long-run economic development, democracies tend to direct their budget more towards public spending that enhance productivity and foster growth (Olson, 1993). Iran provides an interesting context to study this phenomenon as it has experienced different political regimes: the autocracy of Pahlavi in which the Shah was the most powerful political figure and the post-1979 Islamic revolution which deals with factionalized semi-democracy.

The goal of this study is to examine how quality of political institutions in Iran has shaped behavior of the state towards patronage (e.g., military spending) and public goods provision (e.g., education and health spending). We first introduce a mechanism through which a government determines its spending behavior. A simple theoretical framework is used to show how an autocratic government is inclined to direct expenditure more towards patronage in order to secure its assets than public goods that enhance the productivity of the entire society. A shift to democracy would reverse this behavior. Empirically, we focus on the case of Iran to quantify the magnitude and significance of political institutions in government military and non-military spending behavior. We use Vector Autoregressive (VAR) model and its applied tools, i.e. impulse response functions and variance decomposition analysis, examining the dynamic relationship between political institutions and different categories of government spending in Iran from 1960 to 2006 . This is the first empirical investigation of dynamic response of military and non-military spending to symmetric and asymmetric shocks in political institutions of Iran. 
Our main results show that a shock in positive changes of quality of political institutions leads to negative and statistically significant response of military spending, as a proxy of patronage in economics, and positive and statistically significant response of education expenditures, as an indicator of public goods provision, in short term. By contrast, shocks in negative changes of political institutions reflects itself in positive response of military spending and negative response of education, health and public order expenditures.

In autocracies a small dominant coalition rules the rest of population. Dictator needs to buy the royalty of this limited coalition by allocating more budget and economic opportunities. Military lobby has been one of the main drivers of persistency of autocracies in history. The close association between the ex-Shah of Iran with the Iranian army and increasing presence of the Iranian revolutionary guards in politics under the Ahmadinejad presidency are some few examples. ${ }^{1}$ By contrast, democracies represent a wide cross section of society and thus need to provide more public goods in a form of education and health rather than securing economic benefits of selected group of citizens in return for their political royalty. There are also examples for this part within the recent history of Iran: the current pro-reform president of Iran, Mr. Rouhani encouraged the revolutionary guard to follow the recommendations of Ayatollah Khomeini -the founder of the Islamic Republic- in "avoiding interfering in political affairs" and do their job "without requesting its share from the nation and the elected government." Another example is related to a set of political and economic reforms under government of Mr. Khatami (1997-2005) in which the main agenda was empowering the Iranian civil society and reducing the role of militants in political economy. Such large scale reforms under Khatami to increase the role of civil society led to anger of revolutionary guards who were observing their economic and

\footnotetext{
${ }^{1}$ For a review of "The Revolutionary Guards' Role in Iranian Politics" see Alfoneh (2008).

${ }^{2}$ For more details see http://www.al-monitor.com/pulse/originals/2014/04/irgc-iran-rouhani.html\#
} 
political rents under attack. On 9 July 1999, a group of top commanders of revolutionary guard issues an open letter addressing the president Khatami, warning about his reform plans and civil society activities:

"Esteemed Mr. Khatami, how long should we watch with tears and regurgitate our own blood while we practice "democracy" laden with chaos and insults, and have Revolutionary patience at the price of letting our System go?.... In conclusion, with complete respect and endearment towards His Excellency, we declare that our patience has come to an end, and we will not permit ourselves any more tolerance in the face of your inaction"”

This trend is also clearly observed in the provision of productivity-enhancing public goods such as education. As depicted in Figure 1, education spending both as a share of total spending and GDP was at a minimum level during the autocratic government of the ex-Shah. Following a jump in the year of revolution 1979, the share of budget devoted to education went had a positive trend (or at least remained relatively high) during the 8 years economically liberal administration of Mr. Rafsanjani. The trend continued in the subsequent 8 years term of the pro-reform Mr. Khatami, elected as president with 70 and 78 percent of the public vote in 1997 and 2001, respectively. The figures had a sharp drop after that the more conservative pro-militant faction took control of the parliament, and even more when Mr. Ahmadinejad took office in 2005.

\footnotetext{
${ }^{3}$ See the English translation of the message at http://www.princeton.edu/irandataportal/laws/proclamations/icrgletter/ and its original text in Farsi at http://www.princeton.edu/irandataportal/laws/proclamations/icrgletter/ICRG_Letter_Persian.pdf
} 
Figure 1. Education Spending in Iran
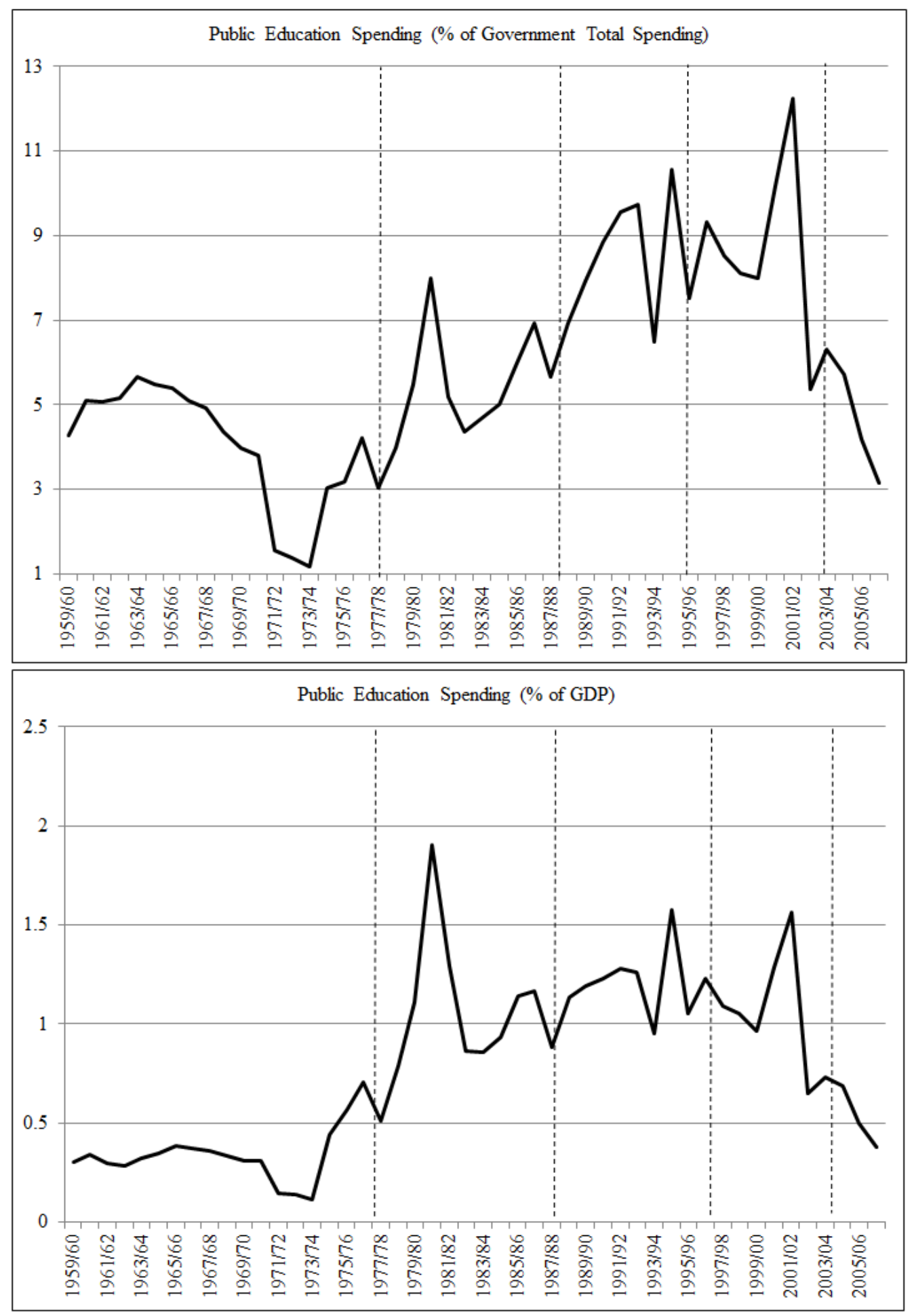

Source: CBI (2014) and authors calculations 
This paper is structured as follows: In Section 2 we present a review of literature on government spending and political institutions nexus. Section 3 presents our theoretical model which leads to some testable propositions. In Section 4 we describe the data we use, and explain empirical methodology and results. Section 5 concludes the paper.

\section{2- Review of theoretical and empirical literature}

Although the relationships among regime type, economic growth, and income distribution are extensively explored in the literature, there is little work devoted to investigating the impact of political system characteristics on the different categories of government expenditures (Brown and Hunter, 1999; Kaufman and Segura-Ubiergo, 2001). Some of the existing studies consider the relationship between democracy and the total amount of the public sector. Aidt and Eterovic (2011) suggest that political competition appears to be negatively correlated with the government size, while the opposite is true for political participation. Moreover, Plümper and Martin (2003), Hausken et al. (2004) and Aidt et al. (2010) find a U-shaped relationship between democracy and public spending. They suggest that for low levels of democracy public spending is high to meet the demands of elites, while for high levels of democracy the usual median voter's model prediction applies and public spending is high due to popular demand of public goods. For medium levels of democracy, however, none of these pressures is active and government spending is at its minimum.

Some other studies have focused on the relationship between democracy and government expenditure in a special area such as military, education, and health. Regarding the military expenditures it is generally believed that as the degree of democracy increases in a country, the military expenditures will decrease. Democratic states are more likely to be at peace and less prone to become involved in international conflicts (James et al., 1999; Oneal and Russet, 1997; 
Lebovic, 2001). Democratic states resolve their domestic conflicts by compromise and nonviolent means, providing an environment where international conflicts between democratic states are also settled peacefully. James et al. (1999) suggest that two democratic states are more likely to have peaceful relations. Lebovic (2001) shows a positive association between quality of democratic institutions and the share of non-military expenditures to the military ones. Also Yildirim and Sezgin (2005) use cross section and panel data for 92 countries from 1987 to 1997 , finding an inverse relationship between the level of democracy and military spending.

There are few studies that investigate the relationship between the characteristics of political systems and education outcomes. Saint-Paul and Verdier (1993) present a model where public education constitutes an instrument of inter-generational redistribution and also creates human capital which promotes long-run growth by raising the human capital of successive generations. In their set-up, democratization rises spending on public education and increases both growth and equalization of income. Brown and Hunter (2004), using time-series cross-sectional analysis, examine the relationship between democracy and education spending in 17 Latin American countries between 1980 and 1997. They show that democracies devote a higher percentage of their educational resources to primary education, the level that benefits the largest segment of the electorate and that is most critical for human capital formation in developing countries. Finally, Besley and Kudamatsu (2006) explore the association between political institutions and health spending in a cross country analysis.

In spirit of Rodrik (2007), a case study analysis as the upcoming analysis helps mitigate concerns about the crucial effect of heterogeneity between countries in cross country regressions when examining the association between political institutions and government spending compositions. Furthermore our empirical approach makes it possible to test our theoretical predictions by 
examining how asymmetric shocks in political institutions reflect itself in allocation of budget to military vs. non-military expenditures in years following initial shock.

\section{3- The model}

We start by introducing a simple theoretical framework that relates a government's decision on public expenditure based on the strength of political institutions. We present a simple case of a small open economy with two sectors to represent a country dependent on trade that cannot influence world prices and takes them as given. ${ }^{4}$ The first sector is controlled by the state and operates through rents from natural resources (oil). Patronage and therefore military spending is a more relevant phenomenon in this sector. A second sector is a private industrial sector ran by entrepreneurs who use human capital as a factor of production. Productivity-enhancing expenditure by the government such as health and education spending enhance skills and is therefore biased towards enhancing the productivity of this sector. ${ }^{5}$ In what follows, we aim to show how the political institutions in the country under study shape the government's investment decision. To fix ideas we consider two extremes. In an autocracy, the state only considers its self-interest and makes decisions maximize its rents and protects its assets against a potential uprising by the population. In a democracy, the government acts as a representative voice of the people, choosing policies that maximize the well-being of the population, i.e. workers.

Preferences are Cobb-Douglas over a homogeneous state good $Y$ and a composite differentiated $\operatorname{good} X$, which is CES over a continuum of varieties of $X$ :

$$
U_{i}=Y^{(1-\beta)} X_{i}^{\beta},
$$

\footnotetext{
${ }^{4}$ Iran is a follower in oil market and global oil prices are determined to a great extent on international markets and affected largely by factors beyond the Iranian economy, e.g. global economic growth, global environmental concerns, energy intensity of oil importers, production of other oil countries, OPEC restrictions and speculation activities among others (for a literature review on market power of the different members of Organization of the Petroleum Exporting Countries (OPEC), see Farzanegan and Raeisian Parvari, 2014).

${ }^{5}$ The state sector may also use skills and gain from education. For our results, it is sufficient that the more skill intensive sector (here the private industry sector $X$ ) benefits more from institutions that augment human capital.
} 


$$
X=\left[\int_{0}^{N} x(i)^{\alpha} d i\right]^{\frac{1}{\alpha}}
$$

where the elasticity of substitution across varieties of $X$ is $\sigma=1 /(1-\alpha)>1$ and $i$ represents an individual. Consumers consider the set of varieties consumed as an aggregate good, $X$, with aggregate price

$$
P_{X}=\left[\int_{0}^{N} p(i)^{1-\sigma} d i\right]^{\frac{1}{1-\sigma}}
$$

Total demand for any variety is

$$
x(i)=\left(\frac{\beta E}{P_{X}}\right)\left(\frac{p(i)}{P_{X}}\right)^{-\sigma}
$$

where $E$ is aggregate expenditure and $\beta E / P_{X}$ is total spending on the composite good $X$.

\section{State good}

The state sector is perfectly competitive with constant returns to scale technology and homogeneous products. There are two factors of production: labor and natural resources. Production function is

$$
Y\left(L_{A}, T\right)=L_{A}^{\eta} T^{1-\eta}
$$

where $L_{A}$ represents workers employed in the state sector and $T$ is natural resources. The state, as the owner of natural resources earns total returns to natural resources:

$$
\operatorname{Tr}=\operatorname{Tp} p_{A}(1-\eta)\left(\frac{L_{A}}{T}\right)^{\eta}=(1-\eta) p_{A} Y
$$

where $r$ represents rents per unit of natural resources, i.e. value of marginal returns to resources, and $p_{A}$ indicates the price of the good produced in the state sector. 


\section{Private industry}

Each good is produced using only labor. Workers have a continuum of skills with $Z \in[0, \infty]$ representing the skill of workers. Each worker produces $\varphi_{X}(Z)$ units of the good, where $\partial \varphi_{X}(Z) / \partial Z>0$. Production in the state sector did not require any skills; therefore all workers employed there produce the same amount regardless of their skill, $\varphi_{Y}(0)=1$.

Firms charge a constant mark up over unit costs. In sector $X$, unit costs of firms is $C_{X}=\frac{W(Z)}{\varphi_{X}(Z)}$.

In a perfectly competitive labor market, wage distribution over $Z$ adjusts to equalize unit costs of firms. Firms minimize their costs given the equilibrium wage distribution.

Given the wage distribution $W(Z)=C_{X} \varphi_{X}(Z)$, there must be some worker with skill $Z^{*}$ who is indifferent about working in the $X$ or the $Y$ sector. We have therefore $w\left(L_{A}, T\right)=W\left(Z^{*}\right)=$ $C_{X} \varphi_{X}\left(Z^{*}\right)$. This gives

$$
C_{X}=\frac{w\left(L_{A}, T\right)}{\varphi_{X}\left(Z^{*}\right)}<w\left(L_{A}, T\right)
$$

where the wage is decreasing in $Z^{*}$ (since it increases $L_{A}$ and $w\left(L_{A}, T\right)$ is negatively related to $L_{A}$ as it is proportional to the marginal product of labor in the state sector), while $\varphi_{X}\left(Z^{*}\right)$ is increasing in $Z^{*}$. Unit cost is therefore a decreasing function of $Z^{*}{ }^{*}$ Since $W\left(Z^{*}\right)$ adjusts to make the least skilled worker in the $X$ sector indifferent between being there or in the state sector, with a reduction in $Z^{*}$ the lowest skilled worker in the $X$ sector is less productive (skilled) than the one before, but he is paid a higher wage. Recall that this threshold wage is set in the background state sector. Decreasing the threshold skill $Z^{*}$ after which workers are hired in the industrial sector all

\footnotetext{
${ }^{6}$ Note that $\varphi_{X}\left(Z^{*}\right)$ is not equal to one because the worker is skilled and has a higher productivity than if it would have worked in the state sector which requires no skills.
} 
else equal has a positive effect on $W(Z)$ for all workers in the $X$ sector because $\varphi_{X}\left(Z^{*}\right)$ falls and $w\left(L_{A}, T\right)$ rises, which in turn increases $C_{X}$. Figure 2 shows the consequences of a reduction in $Z^{*}$. We see that the horizontal curve representing $\log w$ shifts up because wages increase. The upward sloping curve $\log \varphi_{X}(Z)+\log C_{X}$ also shifts up because while $\varphi_{X}(Z)$ remains the same (skills of workers are not influenced), $C_{X}$ increases. Furthermore, $C_{X}$ increases by more than the rise in $w\left(L_{A}, T\right)$ because $C_{X}=w\left(L_{A}, T\right) / \varphi_{X}\left(Z^{*}\right)$ from $(7)$ and $\varphi_{X}\left(Z^{*}\right)$ is increasing in $Z^{*}$.

Figure 2. A Shift of Labor to the Industry Sector

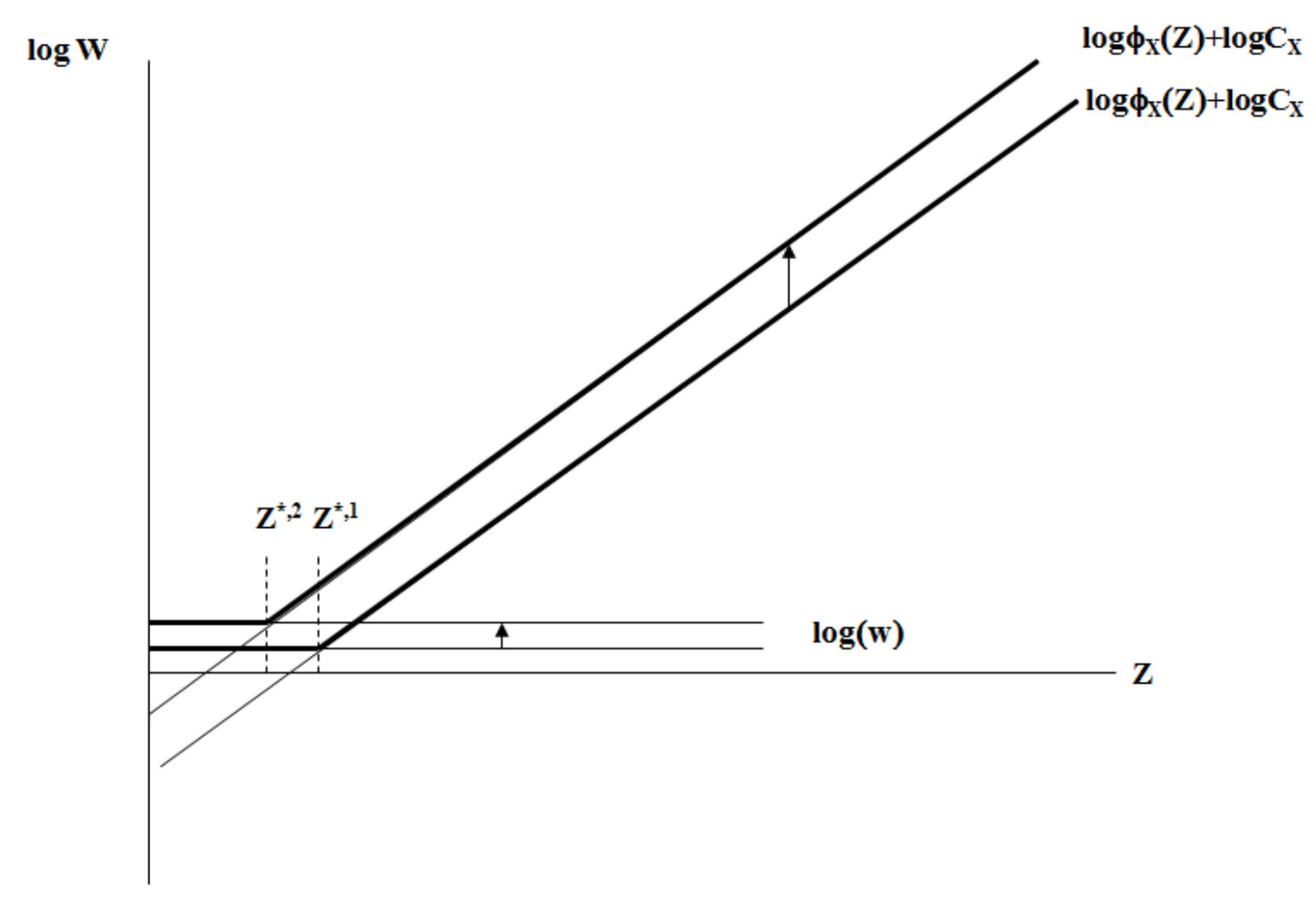

\section{Investment in education}

Investment in education increases the skills of all workers. Since skills are not used in the state sector, we can consider an increase in the productivity of every worker in the $X$ sector: an increase in $\varphi_{X}(Z)$ by a productivity factor $\gamma$, i.e. $\varphi_{X}(Z) \equiv \varphi_{X}(Z, \gamma)$ with $\partial \varphi_{X} / \partial \gamma>0$. 
In this situation we know that the equality $C_{X}=\frac{w\left(L_{A}, T\right)}{\varphi_{X}\left(Z^{*}, \gamma\right)}$ must be satisfied. Note that the left hand side of the equality $C_{X}$ is a constant, so an increase in $\gamma$ must be accompanied by a reallocation of workers from the $Y$ to the $X$ sector to return to equilibrium. Investment in education hence directly increases the denominator, which must then be followed by a decrease in $Z^{*}$. The latter lowers the denominator and increases the numerator $w\left(L_{A}, T\right)$ due to a lower number of workers in the $Y$ sector to offset the direct effect of a higher $\gamma$.

Figure 3. Investment in Productivity-Enhancing Institutions

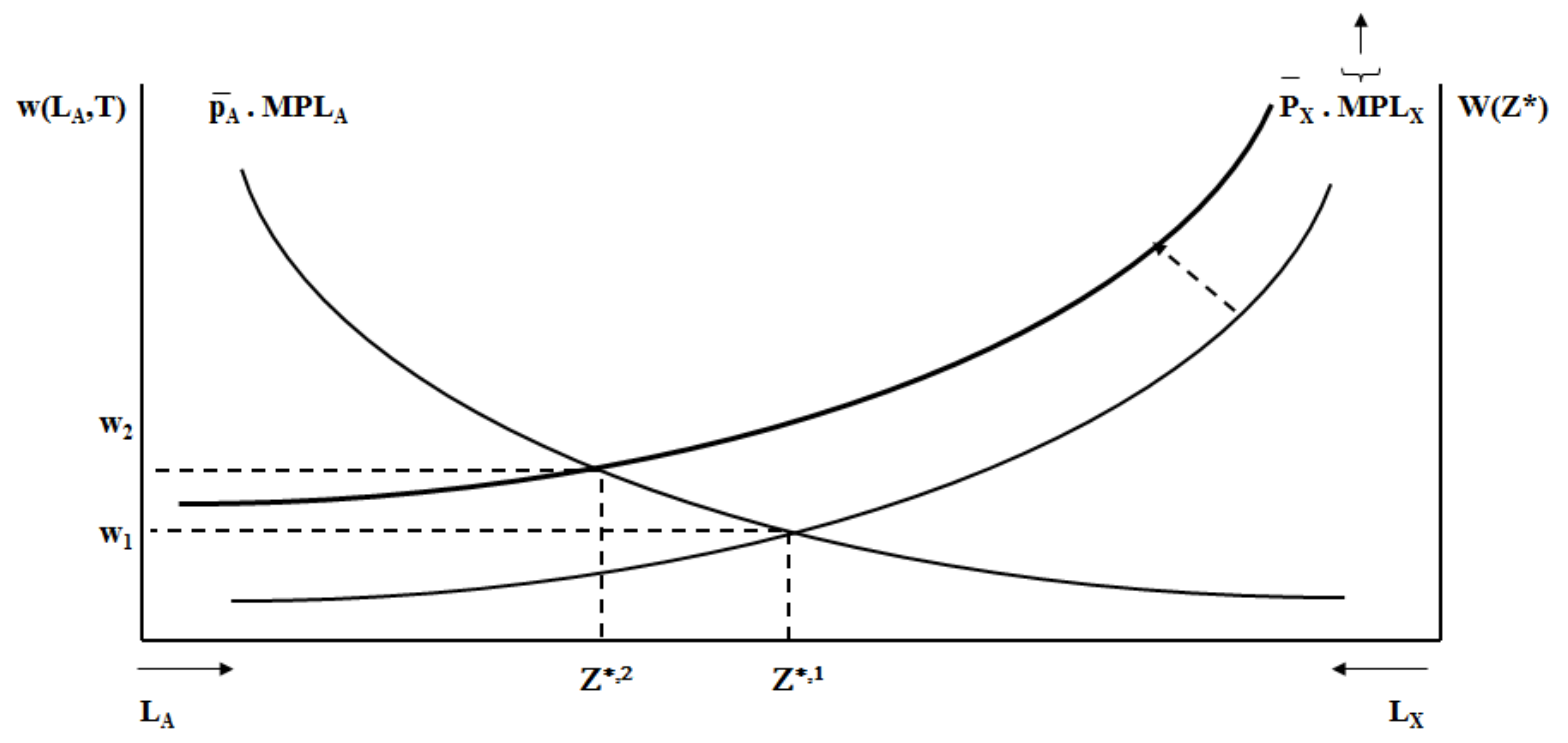

Lemma 1: Investment in education leads to a shift of workers into the industry, which decreases the threshold skill level $Z^{*}$ and increases wages in the state sector.

Figure 3 shows the consequences of investment in education in the economy. Since this increases the marginal productivity of labor in the industry sector and in the state sector, wages rise throughout the whole economy.

\footnotetext{
${ }^{7}$ As $Z^{*}$ unambiguously decreases when investment in education by the state increases the skills of all workers, $\varphi_{X}(Z)$ must increase for all workers, therefore also $\varphi_{X}\left(Z^{*}\right)$ increases.
} 


\section{Political Economy}

Maximization of the utility of each individual under the budget constraint $I^{i}=p_{A} Y^{i}+P_{X} X^{i}$, where $I^{i}$ is income, gives the optimal consumption of goods $Y$ and $X: X^{i *}=\beta \frac{I^{i}}{P_{X}}, Y^{i *}=(1-\beta) \frac{I^{i}}{p_{A}}$.

Note that income is equal to expenditure as no savings take place. We can rewrite indirect utility from consumption as:

$$
V^{i *}=\left(X^{i *}\right)^{\beta}\left(Y^{i *}\right)^{1-\beta}=\beta^{\beta}(1-\beta)^{1-\beta} \frac{E^{i}}{p_{A}^{1-\beta} P_{X}^{\beta}}
$$

Consider an autocracy. Using (8), the total utility of the owners of natural resources is

$$
V^{S}-\frac{m^{2}}{2}-\frac{e^{2}}{2}=f(m) \lambda \frac{(1-\eta) Y\left(L_{A}, T\right)}{\left(\frac{P_{X}}{p_{A}}\right)^{\beta}}-\frac{m^{2}}{2}-\frac{e^{2}}{2}
$$

where we used $I^{S}=\operatorname{Tr}=(1-\eta) p_{A} Y\left(L_{A}, T\right)$ as the income of the state as the owner of natural resources in the economy, $m$ and $e$ stand for military and education spending respectively, and $\lambda=\beta^{\beta}(1-\beta)^{1-\beta}$ is a constant. The expression $0 \leq f(m) \leq 1$ represents the probability that the incumbent state retains power and therefore holds on to the resource rents. This probability is increasing as the state invests in military to defend its stakes both domestically and internationally: $f^{\prime}(m)>0$, giving an optimal level of military spending

$$
m^{*}=f^{\prime}(m) \lambda \frac{(1-\eta) Y\left(L_{A}, T\right)}{\left(\frac{P_{X}}{p_{A}}\right)^{\beta}}
$$

that makes marginal return of such investment equal to its marginal costs. In addition, a larger military spending is optimal at times of turmoil and instability since $f^{\prime}(m)$ is large as opposed to 
times of peace, or democracy when the population is content and there is no risk of the government being overthrown, i.e. $f(m)$ is large and $f^{\prime}(m)$ approaches zero. We can hence state

Lemma 2: An autocratic state which owns the natural resources of an economy is more inclined to invest in military than a democratic regime in order to defend its rents.

A democracy maximizes the indirect utility of the population, which is

$$
\begin{aligned}
& V^{A}=\lambda \frac{\eta Y\left(L_{A}, T\right)}{L_{A}\left(P_{X} / p_{A}\right)^{\beta}}=\lambda \frac{\eta}{\left(P_{X} / p_{A}\right)^{\beta}}\left(\frac{T}{L_{A}}\right)^{1-\eta}, \\
& \mathrm{V}^{\mathrm{X}}=\lambda \frac{\eta}{\left(\mathrm{P}_{\mathrm{X}} / \mathrm{p}_{\mathrm{A}}\right)^{\beta}}\left(\frac{\mathrm{T}}{\mathrm{L}_{\mathrm{A}}}\right)^{1-\eta} \frac{\varphi(\mathrm{Z}, \gamma)}{\varphi\left(\mathrm{Z}^{*}, \gamma\right)}=\mathrm{V}^{\mathrm{A}} \frac{\varphi(\mathrm{Z}, \gamma)}{\varphi\left(\mathrm{Z}^{*}, \gamma\right)},
\end{aligned}
$$

for a worker in the state and the industry sector with incomes $I^{A}=w\left(Z^{*}, T\right)=\eta p_{A} Y\left(L_{A}, T\right) / L_{A}$ and $W(Z)=w\left(Z^{*}, T\right) \varphi(Z, \gamma) / \varphi\left(Z^{*}, \gamma\right)$, respectively.

Equations (9), (11) and (12) can be used to study the political economy of investment in education by calculating its effect on the indirect utility of the different groups in the society. For this analysis we have to look at the effect of $\gamma$ on $Z^{*}$, which is always negative as the relative price is fixed at the world levels. Looking at (9), the indirect utility of the resource owners is proportional to production in the state sector. While the denominator remains unchanged, $Y\left(L_{A}, T\right)$ in the numerator falls. The autocratic state therefore lowers education expenditure as it would lose from a lower $Y\left(Z^{*}, T\right)$ caused by an increase in $\gamma$. State workers on the other hand gain from a reduced number of workers in that sector following a lower threshold $Z^{*}$, hence higher wages. Workers in the industry sector also gain from the positive impact of more education spending on state workers as their wages also rise due to a higher unit $\operatorname{cost} C_{X}$ in their sector. Wages of 
workers in this sector also depend on the individual productivity of a worker over the base productivity of the worker at the margin (lowest skill level in the sector $Z^{*}$, namely $\varphi(Z, \gamma) / \varphi\left(Z^{*}, \gamma\right)$ : more skills imply higher gains. Thus, a more democratic state that accounts for the voice of the population would spend more on education. ${ }^{8}$

In sum, the political economy of education institutions hence depends on the distribution of power in the society. In an autocracy, were the state makes decision based on its self-interest, education investment are not a priority and are diverted to defense expenses that help protect their rents. If policies are democratically decided by the population, investment in education is more appealing as all workers gain from enhanced skills. As better education institutions do not result in a change in $P_{X} / p_{A}$ (no substitution effect) and increase $w\left(L_{A}, T\right)$ and hence $V^{A}$ in (11) with a reduction in $Z^{*}$, they result in a positive income effect for all workers. Skilled workers gain even more because they experience an additional positive skill premium effect in $V^{X}$ in (12).

Proposition 1: While military spending increases a state's capacity to hold on to its rents, investment in education decreases $Z^{*}$, thereby reducing state's income from resources and benefiting all workers through higher wages. Thus, autocracies prefer to allocate expenditure on military rather than education, while democracies invest more in education institutions.

We now confront this question from an empirical point of view for the case of Iran, which has experienced remarkable swings in its political regime in the last decades. Iran is also an interesting case as benefits from oil rents rarely get distributed within the society, creating full divergence between the vested interests of the state elite and that of its citizens.

\footnotetext{
${ }^{8}$ Note that even if natural resource rents get distributed among the population and thus benefit all in a democracy, education spending would still be relatively higher than that in an autocracy due to its positive effect in expressions (11) and (12), which would be added to the negative impact on (9) to measure total welfare under a democratic state.
} 


\section{4- Research design}

\section{Data description}

To examine the dynamic interconnections between political institutions and the structure of the Iranian government spending, we use the following variables: Military expenditures (ldefetot), public order and disciplinary expenditures (ldiciptot), education expenditures (ledutot), health and medical services expenditures (lhealthtot), and cultural and recreational services expenditures (lculttot) from the Central Bank of Iran (CBI) online database in constant 1997 prices. These variables are expressed as their share in total government expenditures and in logarithmic form. Moreover, we use the Polity index as a widely used measure of political institutions (Marshall et al., 2012). This variable describes combinations of autocratic and democratic characteristics of the institutions of government (Marshall et al., 2012). Subtracting the autocracy score from the democracy score yields a summary measure Polity. This index is from -10 (full autocracy) to 10 (full democracy). The higher scores means a more open and competitive political system. For robustness tests we also use the objective democracy indicator

of Vanhanen (2011). We use annual data from 1960 to 2006 for our analysis. Appendix A presents the summary statistics of variables in our analysis.

Our theoretical model leads to the following hypotheses:

H1: Increasing shocks to positive changes of political institutions lead to negative and statistically significant response of military vs. non-military spending of Iran.

H2: Increasing shocks to negative changes of political institutions lead to positive and statistically significant response of military vs. non-military spending of Iran. 


\section{Methodology}

We use the VAR model to estimate the interrelationships among our variables. The VAR provides a multivariate framework relating changes in a particular variable to changes in its own lags and to changes in (the lags of) other variables:

$y_{t}=A_{1} y_{t-1}+\cdots+A_{p} y_{t-p}+B x_{t}+\varepsilon_{t}$

Where $y_{t}$ is a vector of $\mathrm{k}$ endogenous variables, $x_{t}$ is a vector of $\mathrm{d}$ exogenous variables, $A_{1}, \ldots, \mathrm{A}_{\mathrm{p}}$ and $\mathrm{B}$ are matrices of coefficients to be estimated, and $\varepsilon_{t}$ is a vector of innovations that may be contemporaneously correlated but are uncorrelated both with their own lagged values and with all of the right-hand side variables.

We define the vector of exogenous variables as $x_{t}=\left[\right.$ constant, $\left.D_{1}, D_{2}\right]$, where $D_{1}$ and $D_{2}$ are dummy variables capturing the 1979 Islamic Revolution and the Iran-Iraq war (1980-88), respectively. Since only lagged values of the endogenous variables appear on the right hand side of the equation, simultaneity is not an issue and OLS yields consistent estimates.

We use an unrestricted VAR models in levels. Firstly, structural VAR models are 'very often misspecified' (Tijerina-Guajardo and Pagan, 2003). Secondly, the Phillips-Perron and ADF unit root tests indicate that all variables are $\mathrm{I}(1)^{9}$. Since all the variables are non-stationary but cointegrated, differencing leads to loss of long run information. Sims (1980), Sims, Stock and Watson (1990), Doan (2000) and Fuller (1976) have argued against differencing. After all, in this study we are interested in impulse response functions rather than interpreting each coefficient of the VAR model (see also Farzanegan and Markwardt, 2009, Farzanegan, 2011, Farzanegan and Raesian Parvari, 2014 and Dizaji and van Bergeijk, 2013 for the similar approach). Thirdly, in

\footnotetext{
${ }^{9}$ These tests include a constant but not a time trend, as recommended by Dickey and Fuller (1979). To determine the number of cointegrating vectors we use the approach of Johansen and Juselius (1990). The test statistics indicate that the hypothesis of no cointegration among the variables can be rejected for Iran. The results reveal that at least three cointegrating vectors exist among the variables of interest.
} 
the short term, which is especially important in our analysis, an unrestricted VAR shows a better performance than a Vector Error Correction Model (for more details see Naka and Tufte, 1997; Engle and Yoo, 1987, Clements and Hendry, 1995 and Hoffman and Rasche, 1996).

The main applied tools in the VAR models estimation are the impulse response functions (IRF) and the variance decomposition analyses (VDC). The dynamic response of macroeconomic variables to innovations in a particular variable can be traced out using the simulated responses of the estimated VAR system (IRF). Thus, the IRF allows us to examine the dynamic effects of shocks to a particular variable (for example democracy) on the different categories of government expenditures. Through IRF we can observe the magnitude and statistical significance of such responses to one standard deviation increase in democracy related variable error (see Stock and Watson, 2001 for more details on IRF). Variance decomposition analysis shows the role and importance of a specific variable innovation in explaining the variance of other variables in the system.

\section{Empirical results}

We use a VAR model with six variables to examine the impact of political changes in Iran on the different categories of government expenditures. In our unrestricted VAR model, the vector of endogenous variables is as follows:

$$
y_{t}=[\text { polity, health, military, disciplinary, education, culture }]
$$

This is our first choice as the Cholesky ordering in the VAR system. The first variable in a prespecified Cholesky ordering has an immediate impact on all other variables (different kinds of government spending) in the system, excluding the first variable and so on. Health, military and disciplinary expenditures followed the first variable in the Cholesky ordering. Finally, education and cultural expenditures are categorized as the most endogenous variables in the VAR system. 
The Iranian government usually changes the share of these two latter costs to increase or maintain military, security, and health costs (we have followed Farzanegan (2011) in ordering of expenditure variables in Iran). We assume that health expenditures are rather sticky, so that they are not affected contemporaneously by other kinds of expenditures. After all, health related issues are one of the top priorities of most governments and they cannot be neglected easily. Military and disciplinary expenditures are also sticky but can still be adjusted more easily during peace time. Finally, political institution quality is the first variable in ordering. This is due to the fact that institutions are to a large extent exogenous in respect to domestic economy. There are historical, cultural, geographical factors which shape institutions. Institutions affect all other variables in the VAR system instantly but get affected by them with some lags.

Determining an optimum lag length for a VAR model is also important. Economic theory usually does not provide any definite guidelines on the appropriate level of lag length in a VAR model. For finding the optimum lag we use information criteria such as LR, FPE (final prediction error), AIC (Akaike information criterion), SC (Schwarz information criterion), and HQ (HannanQuinn information criterion). We select the lag length of 2 on the basis of the LR, FPE, and AIC criteria and also with respect to stability and diagnostic tests.

\section{Impulse response functions}

In this study, the impulse response functions trace out the simulated response of current and future values of all endogenous variables such as different categories of the Iranian government expenditures (military, education, disciplinary, health, and cultural) to a one standard deviation increasing shock in the political quality of institution. In other words, we estimate the direction and significance of military spending response (among other responses) to political institutions shocks over time after initial shock. The middle line in IRFs displays the response of different 
government expenditures to a one standard deviation shock in Polity variable. The dotted lines represent confidence bands at $68 \%$ confidence intervals which are built by using 1000 Monte Carlos simulations (see Sims and Zha, 1999 who suggest using one standard deviation for error bands in the IRFs). If the confidence intervals include the zero horizontal line, then the impulse response for that specific period after initial shock is not statistically significant (Berument et al., 2010). In other words, the null hypothesis of "no effects of political variable" on the specific government expenditure cannot be rejected. The horizontal line in IRFs shows the time period (years) after the initial shock. The vertical line in IRFs shows the magnitude of response to shocks. Figure 4 displays the impulse responses of different categories of the Iranian government expenditures to a one standard deviation shock in Polity for a period of 1960-2006.

The Polity shock was identified on the basis of a standard Cholesky factorization, ordering Polity first followed by health, military, security, education and cultural expenditures (as $\%$ of total expenditures and all variables in logarithmic form except for Polity). Figure 4 shows that the increasing shocks to Polity (higher political openness) have statistically significant and negative effect on government military expenditures. Military spending reduction in the short term (3 years after democratic shock) is statistically significant. This is in line with previous literature in which democratic development of the political system is associated with lower size of patronage spending. Interesting the short term responses of education, health, disciplinary and order spending to increasing shocks in Polity index is positive and significant. 
Figure 4. Impulse responses to one standard deviation shock in Polity index

\section{Response to Cholesky One S.D. Innovation in Polity}
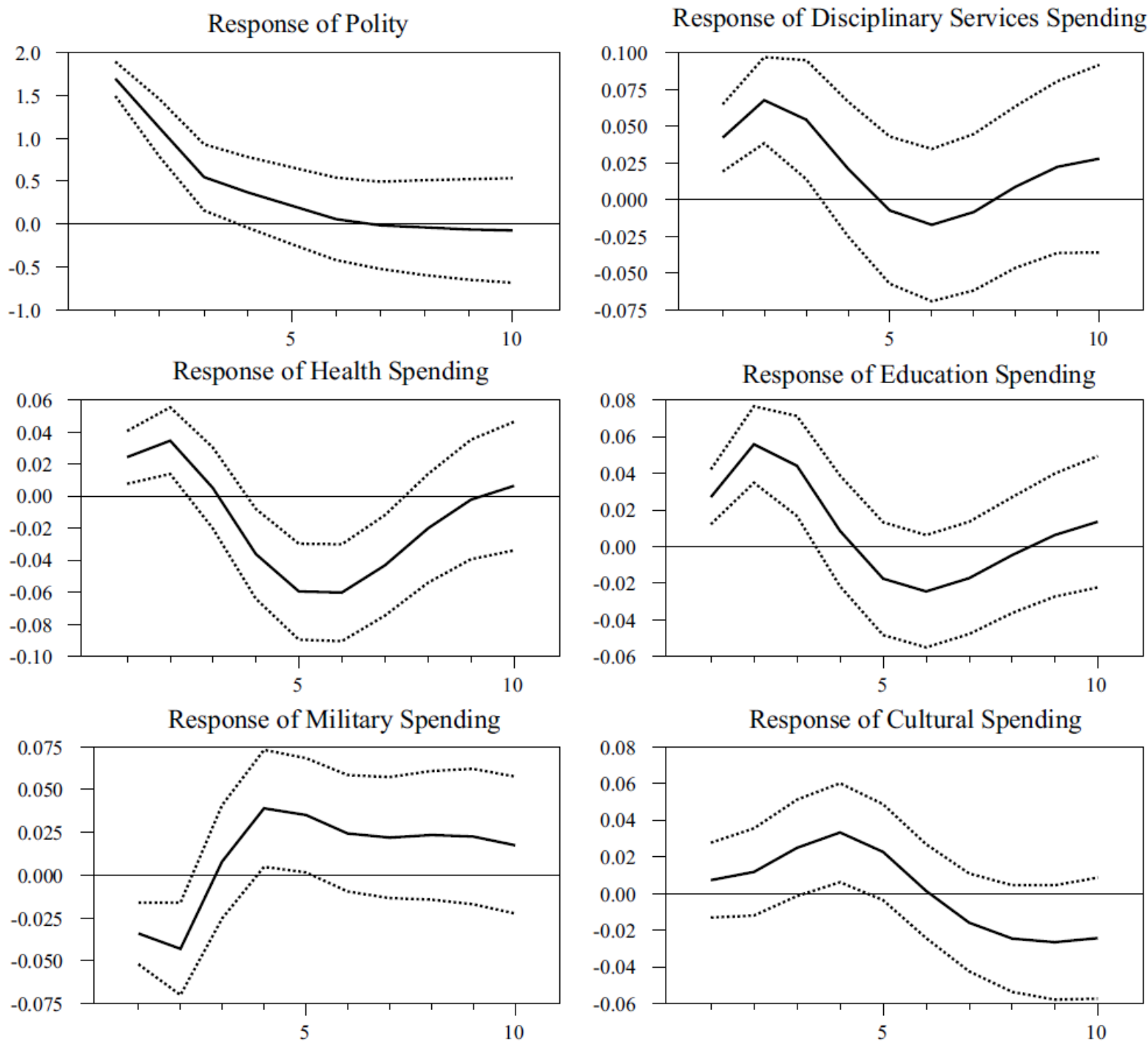

Note: The graphs show impulse responses of different kinds of government spending (as \% of total government spending) to one-standard-deviation increasing shocks in Polity. The dotted lines represent \pm 1 standard deviation. The deviation from the baseline scenario of no shocks is on the vertical axis; the periods (years) after the shock are on the horizontal axis. The vertical axis shows the magnitude of the responses. All variables (except for Polity index) are used in logarithmic and real form.

Also we have examined the diagnostic statistics of the estimated VAR model. For stability of our model, Figure 5 shows the AR graph which reports the inverse roots of the characteristic AR polynomial. This figure shows that in the VAR model all roots have modulus less than one and lie inside the unit circle and the VAR model is stable (or stationary). 
Figure 5. Inverse roots of AR Characteristic Polynomial

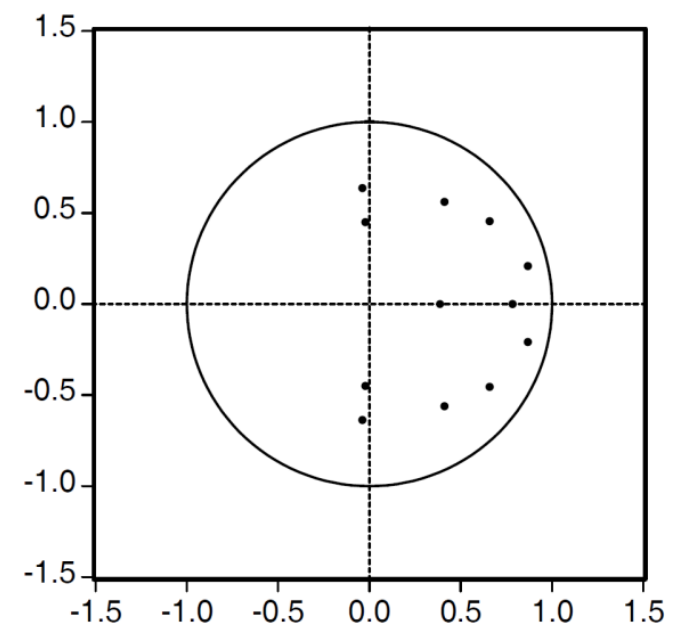

Moreover the results of autocorrelation LM test in Table 1 show lack of auto-correlation in the estimated VAR model's residuals. Overall our diagnostic criteria show that our estimated VAR model which is a basis for the impulse response functions in Figure 4 is stable and satisfactory.

Table 1. VAR residual Serial correlation LM test

\begin{tabular}{lll}
\hline \hline Lags & LM-Test & P-value \\
\hline 1 & 47.4 & 0.09 \\
2 & 34.2 & 0.55 \\
3 & 42.5 & 0.21 \\
4 & 23.3 & 0.94 \\
5 & 46.9 & 0.10 \\
6 & 35.3 & 0.50 \\
7 & 42.2 & 0.21 \\
8 & 35.3 & 0.49 \\
\hline \hline
\end{tabular}

Note: Null hypothesis: no serial correlation at lag order $\mathrm{h}$

Variance decomposition

How much of the variance in military spending (and other forms of spending) is explained by shocks in the military spending and how much is explained by shocks in the political institutions (among the shocks in other variables)? The variance decomposition (VDC) results in Table 2 
shows the variance of each variable from each source of shock. The first vertical column tells the number of years following a shock to which the decomposition applies and the row figures gives the fraction of variance explained by the shock source.

Table 2 shows that for almost all variables, the largest portion of variation is explained by their own trend in the first year. Hence at the start of the simulations the historical trend of each variable explains a large part of its own variation. Polity shocks play an important role in explaining the variation of the other variables in the long run (Its contributions in explaining the shocks to ldefetot and ledutot are about $14 \%$ and $19 \%$ in $10^{\text {th }}$ year). The contribution of Polity shocks to government health expenditure shocks was about $10 \%$ in the first year rising to about $26 \%$ in the eighth year. The major part of the variations in military expenditures is explained by its own shocks in all years. However the shocks to Polity and disciplinary expenditures also affect the variance of the military expenditures significantly.

As is evidenced in table 2, shocks to cultural expenditures explained about 31 and $28 \%$ of variation of education expenditures and disciplinary expenditures in the $10^{\text {th }}$ year. This implies that considerable causalities can exist from cultural expenditures to education expenditures and disciplinary expenditures. Additionally, the results show that forecast errors in Polity other than its own variations are mostly due to variations in education expenditures, disciplinary expenditures and military expenditures respectively. 
Table 2. Variance decomposition

\begin{tabular}{|c|c|c|c|c|c|c|}
\hline $\begin{array}{l}\text { shock } \\
\text { source }\end{array}$ & POLITY & LHEALTHTOT & LDEFETOT & LDICIPTOT & LEDUTOT & LCULTTOT \\
\hline \multicolumn{7}{|c|}{ Variance decomposition of POLITY } \\
\hline 1 Year & 100 & 0.00 & 0.00 & 0.00 & 0.00 & 0.00 \\
\hline 2 Years & 87.50 & 1.64 & 0.04 & 5.33 & 5.47 & 0.00 \\
\hline 5 Years & 62.03 & 1.76 & 2.36 & 19.76 & 13.70 & 0.38 \\
\hline 8 Years & 52.16 & 1.81 & 3.86 & 20.06 & 21.62 & 0.48 \\
\hline 10 Years & 51.18 & 1.79 & 4.61 & 19.70 & 21.86 & 0.86 \\
\hline \multicolumn{7}{|c|}{ Variance decomposition of LHEALTHTOT } \\
\hline 1 Year & 6.79 & 93.21 & 0.00 & 0.00 & 0.00 & 0.00 \\
\hline 2 Years & 11.32 & 77.02 & 0.96 & 8.27 & 1.67 & 0.75 \\
\hline 5 Years & 20.47 & 43.86 & 0.93 & 18.63 & 1.75 & 14.36 \\
\hline 8 Years & 26.24 & 30.01 & 2.97 & 22.59 & 8.23 & 9.95 \\
\hline 10 Years & 22.78 & 26.13 & 4.51 & 22.67 & 15.08 & 8.83 \\
\hline \multicolumn{7}{|c|}{ Variance decomposition of $\angle D E F E T O T$} \\
\hline 1 Year & 9.97 & 4.58 & 85.45 & 0.00 & 0.00 & 0.00 \\
\hline 2 Years & 11.09 & 4.08 & 80.16 & 2.99 & 1.13 & 0.53 \\
\hline 5 Years & 13.87 & 5.26 & 68.93 & 8.19 & 1.00 & 2.75 \\
\hline 8 Years & 13.79 & 6.87 & 54.25 & 15.59 & 4.61 & 4.90 \\
\hline 10 Years & 13.73 & 6.33 & 49.85 & 16.78 & 8.37 & 4.94 \\
\hline \multicolumn{7}{|c|}{ Variance decomposition of LDICIPTOT } \\
\hline 1 Year & 9.8 & 6.97 & 6.18 & 77.04 & 0.00 & 0.00 \\
\hline 2 Years & 18.30 & 3.68 & 5.20 & 62.50 & 0.87 & 9.45 \\
\hline 5 Years & 11.96 & 2.40 & 3.14 & 47.56 & 2.65 & 32.30 \\
\hline 8 Years & 10.65 & 5.01 & 2.83 & 48.79 & 2.77 & 29.95 \\
\hline 10 Years & 11.33 & 5.45 & 2.73 & 48.72 & 2.94 & 28.83 \\
\hline \multicolumn{7}{|c|}{ Variance decomposition of LEDUTOT } \\
\hline 1 Year & 9.26 & 14.03 & 2.89 & 8.84 & 64.98 & 0.00 \\
\hline 2 Years & 22.38 & 10.11 & 2.80 & 4.07 & 51.25 & 9.37 \\
\hline 5 Years & 19.50 & 7.66 & 1.81 & 6.69 & 33.70 & 30.64 \\
\hline 8 Years & 19.24 & 8.04 & 3.41 & 7.27 & 29.58 & 32.47 \\
\hline 10 Years & 18.60 & 8.56 & 4.00 & 7.99 & 29.48 & 31.37 \\
\hline \multicolumn{7}{|c|}{ Variance decomposition of LCULTTOT } \\
\hline 1 Year & 0.38 & 0.19 & 6.95 & 2.16 & 0.43 & 89.90 \\
\hline 2 Years & 0.87 & 3.03 & 4.77 & 1.56 & 1.66 & 88.11 \\
\hline 5 Years & 8.28 & 6.23 & 5.14 & 3.41 & 3.85 & 73.07 \\
\hline 8 Years & 9.30 & 6.83 & 6.70 & 4.79 & 10.33 & 62.05 \\
\hline 10 Years & 11.70 & 6.95 & 6.29 & 8.77 & 9.66 & 56.62 \\
\hline
\end{tabular}




\section{Robustness analyses}

\section{a. Generalized impulse responses}

Ordering of variables in the VAR system is important in order to calculate the IRFs and VDC analyses. Different ordering may result in different IRF results. In order to avoid the difficulties of identifying orthogonal shocks in VAR models, Pesaran and Shin (1998) introduced Generalized Impulse Responses (GIR). The GIR functions construct an orthogonal set of innovations that does not depend on the VAR ordering. For comparison, we calculate the generalized impulse responses of the different compositions of government spending to total government spending ratio to a one standard deviation increasing shock in Polity. The responses are similar to those which we obtained using Cholesky one standard innovation ${ }^{10}$.

\section{b. Alternative definition for quality of political institutions variable (Vanhenen index)}

We use also an alternative institutional quality indicator called Vanhanen index (VI). The Vanhanen index of democratization is defined as the product of two underlying indices for political competition and political participation (Vanhanen, 2011). Since considering the effects of political changes on the different categories of the government expenditures is a key issue of our analysis, it is important Polity and VI measures do not only differ conceptually, but that their measurement also differs (Polity scores are subjective/judgmental while Vanhanen deploys numerical voting records). Consequently, the two indicators show different patterns of variation. The Vanhanen index is taken directly from the Finnish Social Science Data Archive (Vanhanen, 2011).

\footnotetext{
${ }^{10}$ Since the GIR results are identical to those obtained by the Cholesky ordering, we have not reported them here. They are available upon request.
} 
For this purpose we re-estimate the VAR model using the same Cholesky ordering (with Vanhanen index instead of Polity) as in previous analysis. Considering the different lag criteria, we use 2 lags as the optimum number of lags in our analysis. We also control for the exogenous shocks of the Islamic revolution and the war period with Iraq. The VAR stability condition test (Roots of Characteristic Polynomial) indicates that the VAR satisfies the stability condition. The impulse response analysis, using Vanhanen index as a shock variable is presented in Figure 6.

Looking at Figure 6 shows that response of disciplinary services and education spending to shocks in Vanhanen index is positive and significant in short term. However, military spending negative response is not statistically significant. Possibly, this is because we should make differences between positive shocks and negative shocks as it has been discussed in the literature of asymmetric shocks by Mork (1989) and Hamilton (1996).

In line with Mork's work which has proposed an asymmetric definition of oil prices in order to distinguish between positive and negative oil price shocks, we define the positive and negative changes in Vanhanen index (VI) as follows:

$\mathrm{MVI}_{\mathrm{t}}+=\max \left(0,\left(\mathrm{VI}_{\mathrm{t}}-\mathrm{VI}_{\mathrm{t}-1}\right)\right)$

$\mathrm{MVI}_{\mathrm{t}^{-}}=\min \left(0,\left(\mathrm{VI}_{\mathrm{t}^{-}}-\mathrm{VI}_{\mathrm{t}-1}\right)\right)$

where $\mathrm{VI}_{\mathrm{t}}$ is Vanhenen index in time t. For more comprehensive details on asymmetric shocks see Mork (1994). 
Figure 6. Impulse responses to one standard deviation shock in Vanhanen index

\section{Response to Cholesky One S.D. Innovation in Vanhanen Index}
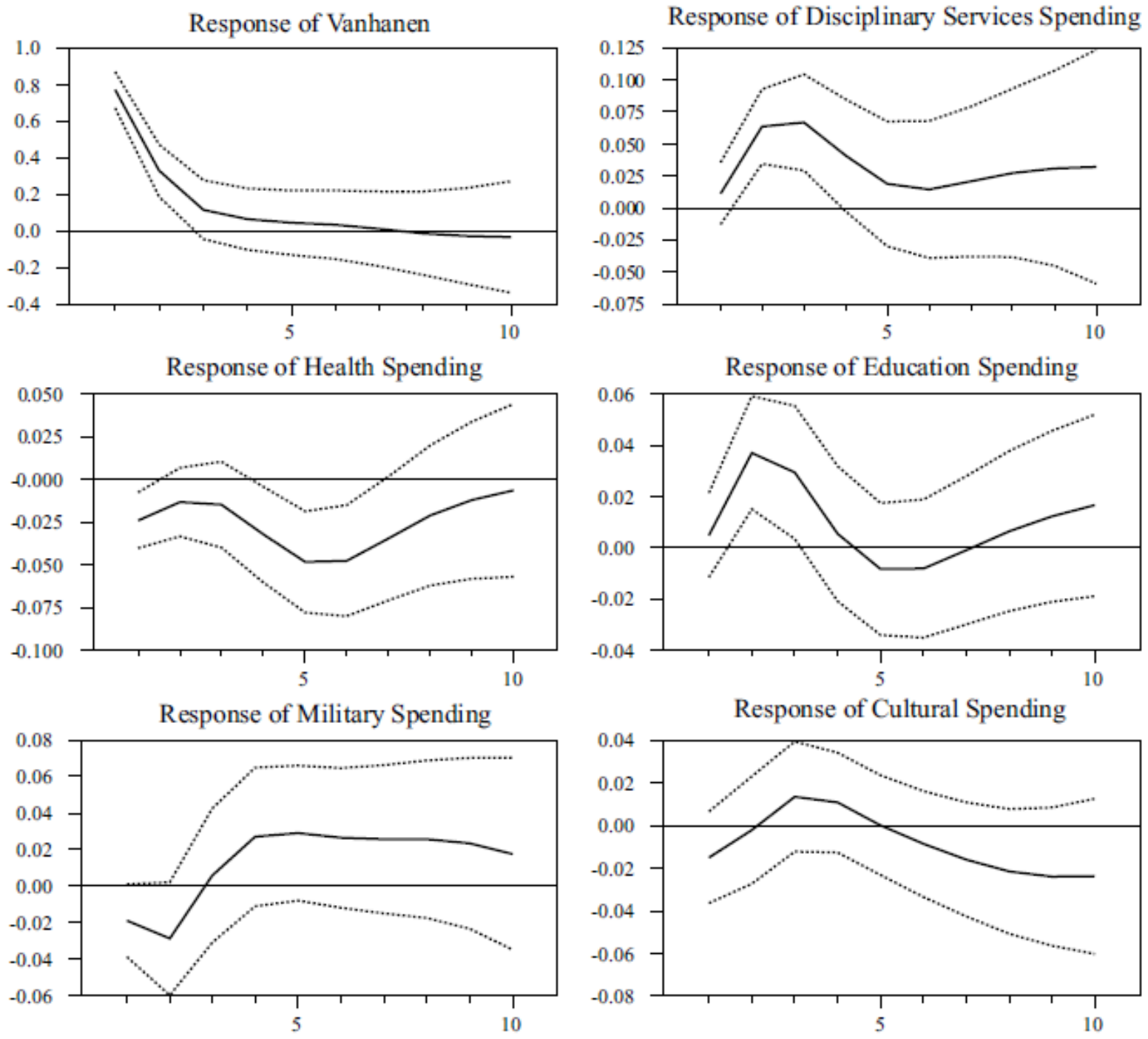

Note: The graphs show impulse responses of different kinds of government spending (as \% of total government spending) to one-standard-deviation shocks in Vanhanen. The dotted lines represent \pm 1 standard deviation. The deviation from the baseline scenario of no shocks is on the vertical axis; the periods (years) after the shock are on the horizontal axis. The vertical axis shows the magnitude of the responses. All variables (except for Vanhanen index) are used in logarithmic form.

Figure 7 shows IRFs based on one standard deviation shock to positive changes in Vanhanen index. We use 1 lag of endogenous variables on the basis of different lag criteria, controlling for 
revolution and war with Iraq exogenous shocks. The results of stability test on our VAR model are also satisfactory ${ }^{11}$.

Figure 7. Impulse responses to one standard deviation shock in positive changes of Vanhanen index (MVI+)

\section{Response to Cholesky One S.D. Innovation in Positive Change of Vanhanen Index}
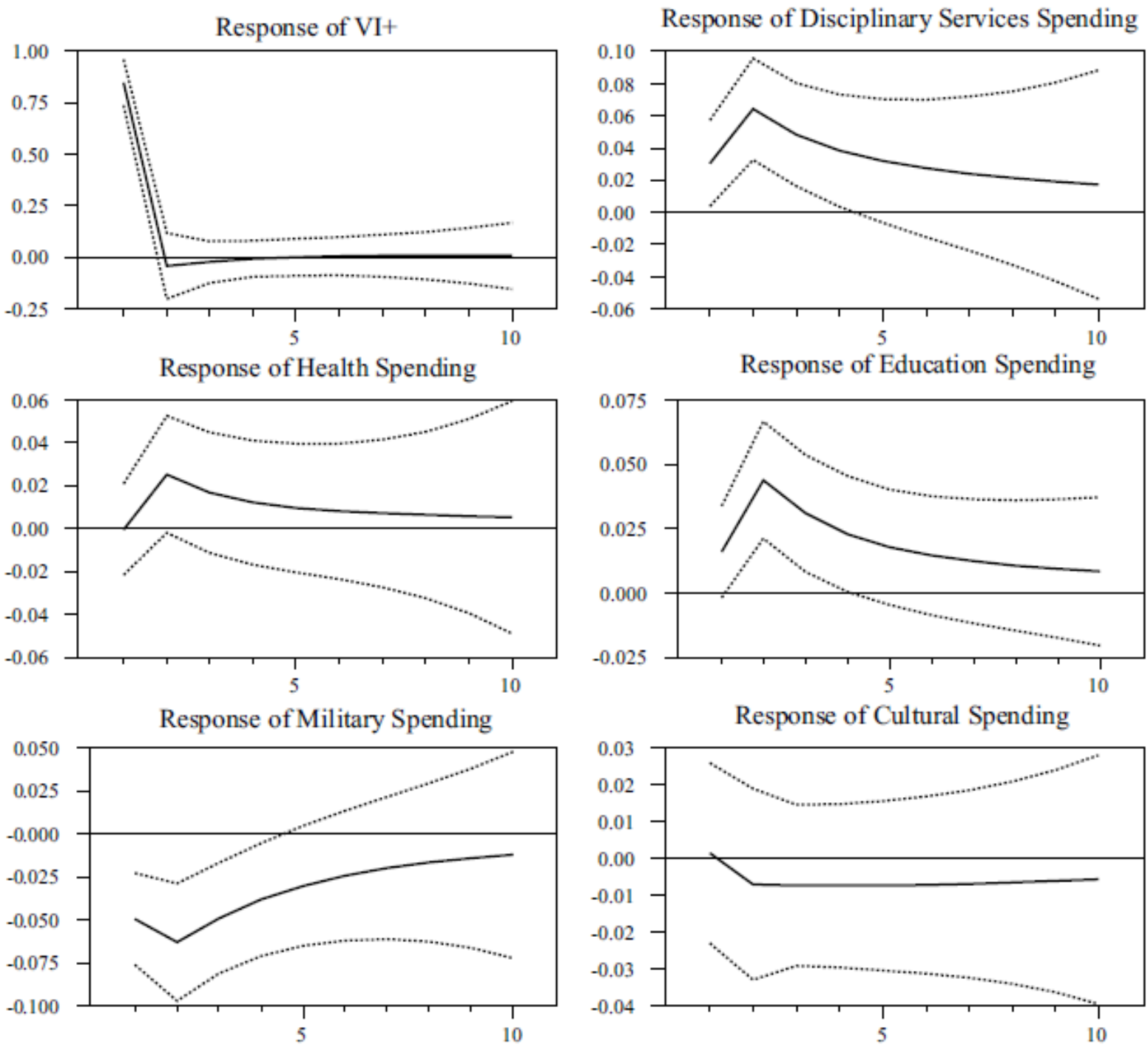

Note: The graphs show impulse responses of different kinds of government spending (as \% of total government spending) to one-standard-deviation shocks in positive changes of Vanhanen. The dotted lines represent \pm 1 standard deviation. The deviation from the baseline scenario of no shocks is on the vertical axis; the periods (years) after the shock are on the horizontal axis. The vertical axis shows the magnitude of the responses. All variables (except for Vanhanen index) are used in logarithmic form.

\footnotetext{
${ }^{11}$ These results are available upon request.
} 
Following shocks in positive changes of the Vanhanen index of democracy, we can see a negative response of military spending which is also statistically significant until five years after initial positive democracy shocks. The military spending response reaches its lowest level in the second year after positive shock in democracy. Education and disciplinary (public order) spending show a positive response to positive democracy shocks which reached their maximum in the second year after shock. These responses are also statistically significant for the first 4 years after initial shock. There results show that positive development in democratic institutions lead to lower patronage spending and higher provision of goods and services which target a larger portion of population demands rather than meeting a small military group.

But what are the reflections of negative changes in democratic quality of institutions? Figure 8 illustrates the response of the relative share of different components of government spending in total budget to negative changes in Vanhanen index. We use 1 lag of endogenous variables on the basis of different lag criteria, controlling for revolution and war with Iraq exogenous shocks ${ }^{12}$.

A one standard deviation increase in absolute values of "negative changes" of Vanhanen index for Iran accompanied with negative responses of the relative shares of government expenditures in health, disciplinary and education. However, these responses are only significant in the first and second years after initial shock. Interesting is also the positive response of military spending to negative developments in democratic institutions. The positive response of military is only statistically significant in the first year after initial negative changes of democracy in Iran. This is again the line of our theoretical expectations. Less democratic states need to spend more on a selected portion of population and society which may provide physical support at the time of

\footnotetext{
${ }^{12}$ The estimated VAR model satisfied the stability and cointegration conditions. The results of these tests are available upon request.
} 
emergency such as revolutions or riots. The opportunity cost of military spending under negative democratic developments is also high: less funding will be available for education, health and public order.

Figure 8. Impulse responses to one standard deviation shock in negative changes of Vanhanen index (MVI-)

Response to Cholesky One S.D. Innovation in Negative Change of Vanhanen Index

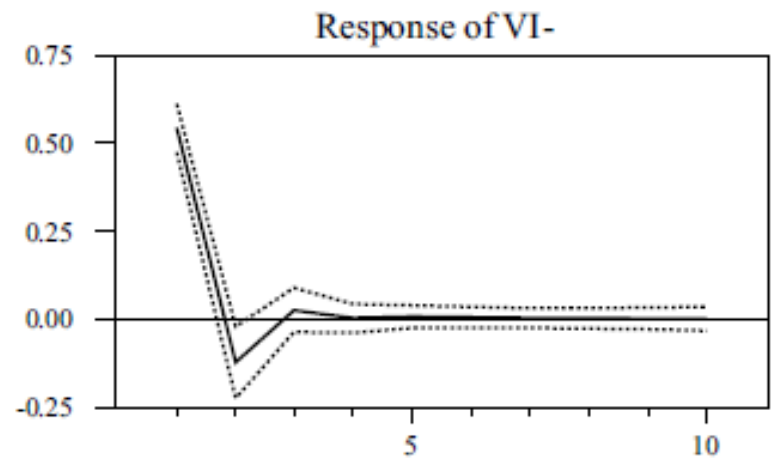

Response of Disciplinary Services Spending
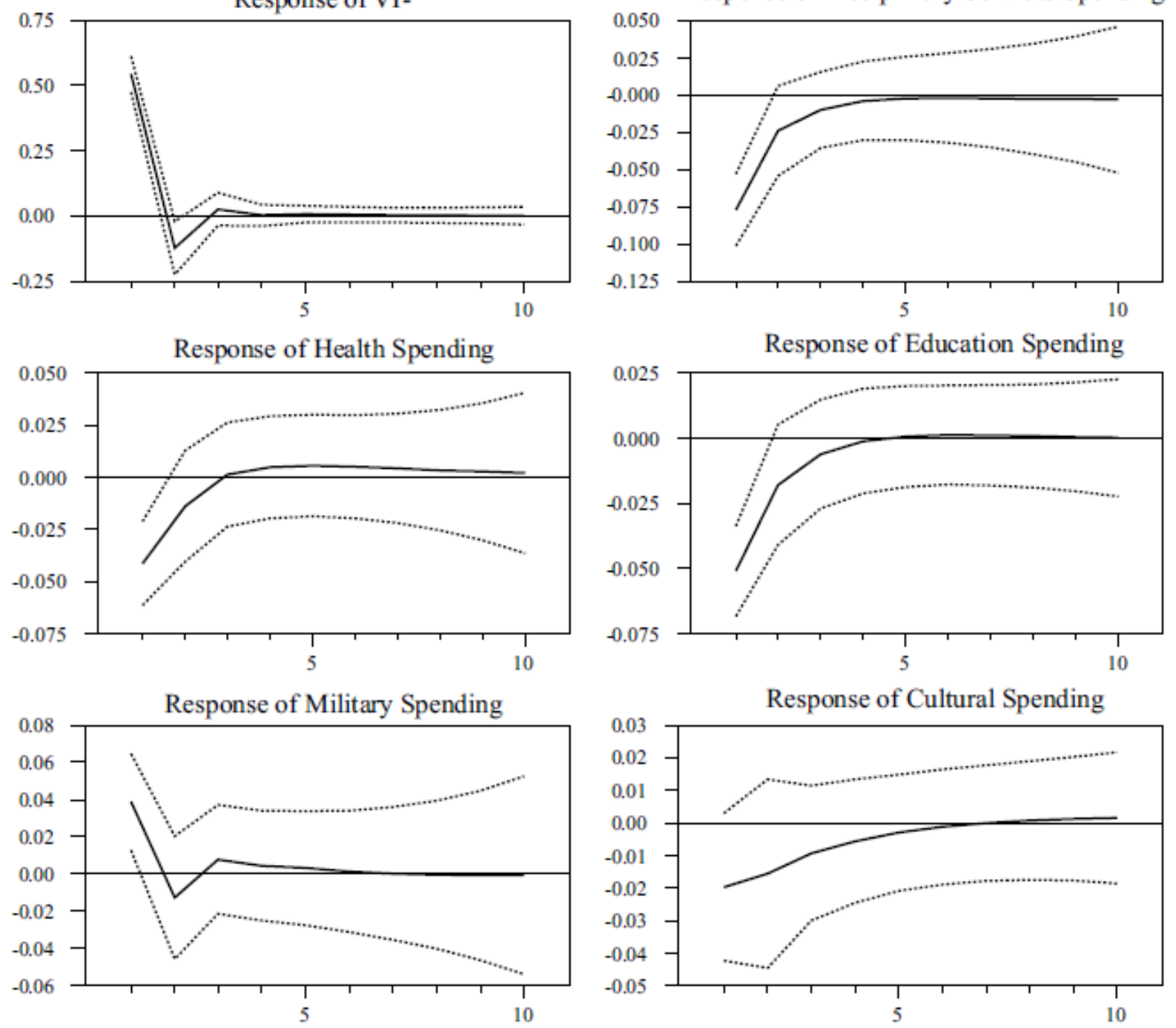

Note: The graphs show impulse responses of different kinds of government spending (as \% of total government spending) to one-standard-deviation shocks in negative changes of Vanhanen. The dotted lines represent \pm 1 standard deviation. The deviation from the baseline scenario of no shocks is on the vertical axis; the periods (years) after the shock are on the horizontal axis. The vertical axis shows the magnitude of the responses. All variables (except for Vanhanen index) are used in logarithmic form. 
In addition to Mork's approach in defining the asymmetric shocks, we also use another definition suggested by Hamilton (1996). In consistence with Hamilton's work which has proposed an asymmetric definition of oil prices, we define the positive and negative changes in Vanhanen index (VI) as follows:

$\mathrm{HVI}_{\mathrm{t}}+=\max \left[0,\left(\left(\mathrm{HI}_{\mathrm{t}}\right)-\max \left(\left(\mathrm{HI}_{\mathrm{t}-1}\right), \ldots,\left(\mathrm{HI}_{\mathrm{t}-4}\right)\right)\right]\right.$

$\mathrm{HVI}_{\mathrm{t}^{-}}=\min \left[0,\left(\left(\mathrm{HI}_{\mathrm{t}}\right)-\min \left(\left(\mathrm{HI}_{\mathrm{t}-1}\right), \ldots,\left(\mathrm{HI}_{\mathrm{t}-4}\right)\right)\right]\right.$

Our findings show that the responses with Hamilton's definition of asymmetric shocks are similar to those which we obtained using Mork's definition. Therefore we have not reported them here ${ }^{13}$.

\section{c. Using the ratio of government expenditures to GDP}

As an alternative specification, we employ the ratio of each components of government spending to GDP instead of their relative share in budget in our impulse response analysis. How innovations in political variable (Polity) affect the distribution of different categories of government spending to GDP ratio? First, we estimate an unrestricted VAR model with an optimum lag number of 2 (on the basis of different lag criteria) and Cholesky ordering of [Polity, health to GDP, military to GDP, disciplinary to GDP, education to GDP, and cultural to GDP]. As in previous analysis, we include revolution and war dummy variables as exogenous shocks. The diagnostic statistics such as VAR stability condition show that no root lies outside of the unit circle and the model is stable. The model also does not show a specific problem with residual autocorrelation on the basis of LM test. Moreover the results of cointegration tests reveal that at least three co-integrating vectors exist among the variables of interest ${ }^{14}$.

\footnotetext{
${ }^{13}$ The results with Hamilton's definition of asymmetric shocks are available upon request.

${ }^{14}$ The diagnostic statistic results are available upon request.
} 
Figure 9. Impulse responses to one standard deviation shock in POLITY index

\section{Response to Cholesky One S.D. Innovation in Polity}

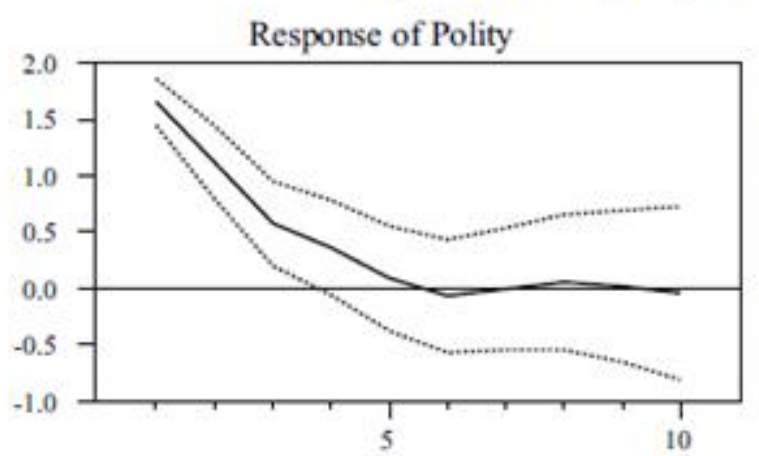

Response of Disciplinary Services Spending (\% GDP)
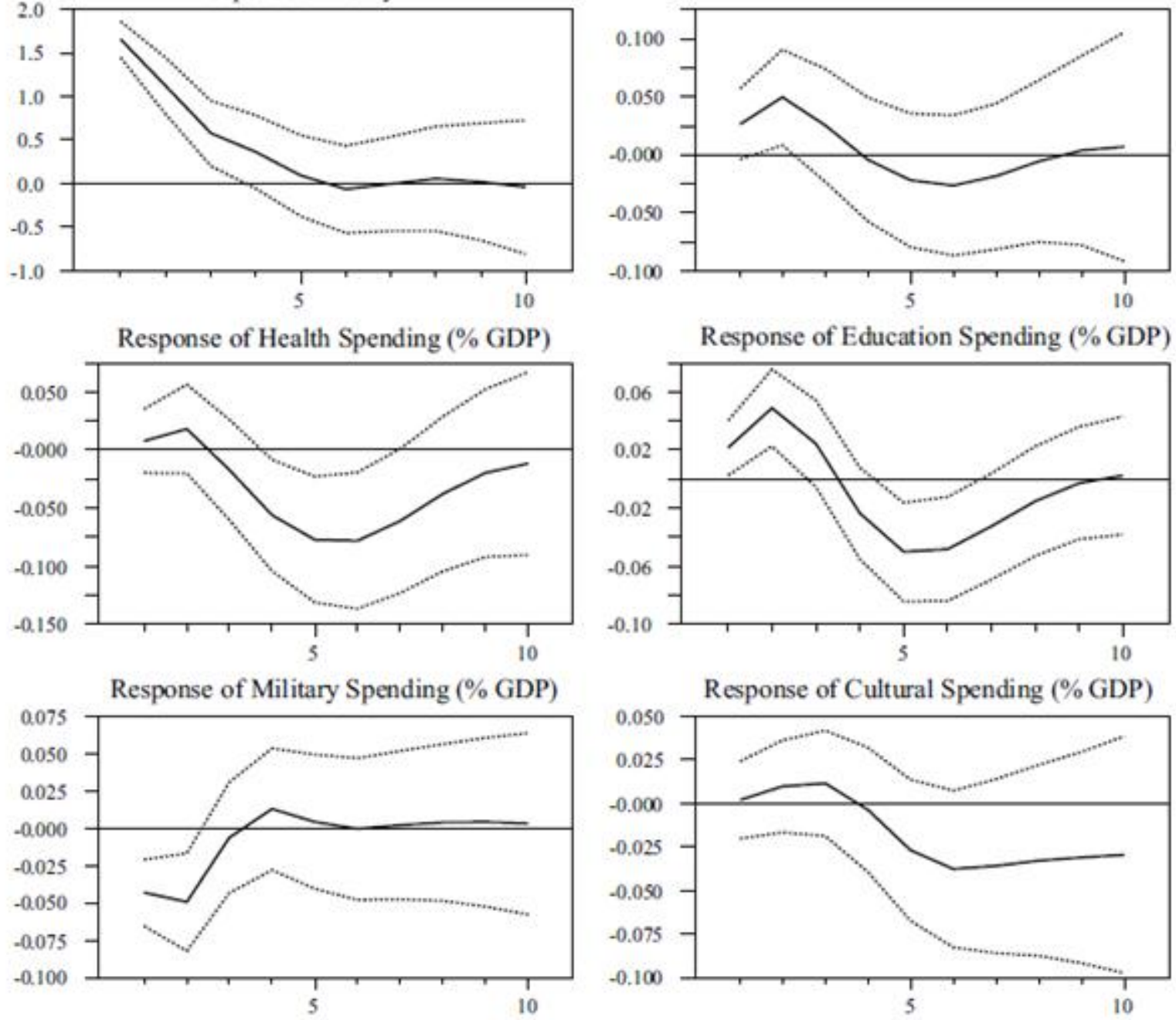

Note: The graphs show impulse responses of different kinds of government spending (as \% of GDP) to onestandard-deviation shocks in Polity index. The dotted lines represent \pm 1 standard deviation. The deviation from the baseline scenario of no shocks is on the vertical axis; the periods (years) after the shock are on the horizontal axis. The vertical axis shows the magnitude of the responses. All variables (except for Polity index) are used in logarithmic form.

Figure 9 shows that a one standard deviation increasing shock in Polity accompanied by initially negative and significant responses in military spending to GDP and positive and significant responses in education spending to GDP within the first 2 years after initial shock, reinforcing 
our earlier results using relative share of spending in the government budget. ${ }^{15}$ Appendix B summarizes the main results of impulse response analyses in our study.

\section{5- Conclusion}

We have examined how positive and negative shocks in political institutions of Iran shape the government budget allocation to military versus productivity enhancing public goods such as education.

A simple theoretical framework is introduced to show the vested interests of different groups in a small resource-oriented economy such as Iran that is dependent on imports and cannot significantly impact world prices. The idea is to show how the political regime in a country can determine the target of government spending, namely military to defend its assets versus productivity-enhancing public expenditure. An autocratic state prefers expenditure on patronage to increase its rents and longevity, whereas a democratic state where the workers play the role of the median voter tend to favor labor productivity enhancing public goods that also result in the expansion of the industry and higher wages.

Using annual data from 1960 to 2006 and impulse response analysis on the basis of unrestricted VAR model, we show that response of military spending to positive changes in quality democratic institutions in Iran is negative and statistically significant for 3 years after initial shock. On the contrary, education spending responds positively to a positive shock towards

\footnotetext{
${ }^{15}$ In addition, we have estimated a VAR model using the per capita form of each components of government spending. We have estimated an unrestricted VAR model with a Cholesky ordering of [polity, lhealthcap, ldefecap, ldicipcap, leducap, lcultcap]. We can find the significant responses only for the defense expenditures. The IRFs show that defense expenditures response both negatively and significantly (within the first 2 years after initial shock) to one standard deviation increasing shock in Polity. We cannot find significant responses regarding to the other kind of expenditures. These results are available upon request.
} 
democratization, which remains statistically significant for the first 4 years reaching its maximum in the second year after shock.

These results show that positive development in democratic institutions leads to lower patronage spending and higher provision of goods and services which target a larger portion of population demands rather than meeting a small military group. Our results contribute to the literature on patronage and public goods provision under different political regimes in a developing country. Our main findings which support theoretical predictions of our model are robust to different specification of government spending and alternative political institution indicators. The results are not sensitive to the ordering of variables in the VAR analysis.

Finally, our approach to this nexus has been also additionally motivated by recent significant international sanctions to change the political behavior of Iranian government. The positive shocks in political institutions that shape the government spending behavior of Iran can for example stem from exogenous pressures of economic sanctions or internal pressures of civil society. An interpretation can be that if the sanctions are successful to increase political openness in Iran in short run (as is shown in Dizaji and van Bergeijk, 2013), then one can also expect to see a reduction in allocated budget for military (patronage) and an increase in education expenditure in Iran. This allows us to also make conclusions about how negative shocks in political institutions through lifting exogenous pressures and/or marginalization of civil society and its idle status may reflect itself in spending structure of the state. Of course, more work on this remains to be done to reveal the indirect link between sanctions and its impact on economic development through the spending behavior of the government in the target country. 


\section{References}

Acemoglu, D., Davide T., Vindigni, A., 2010. A theory of military dictatorships. American Economic Journal: Macroeconomics, 2, 1-42.

Aidt, T.S., Dutta, J., Dauntan, M., 2010. The retrenchment hypothesis and the extension of the franchise in England and Wales. The Economic Journal 120, 990-1020.

Aidt, T.S., Eterovic, D.S., 2011. Political competition, electoral participation and public finance in 20th century Latin America. European Journal of Political Economy 27, 181-200.

Alfoneh, Al., 2008. The revolutionary guards' role in Iranian politics. Middle East Quarterly $15,3-14$.

Berument, M.H., Ceylan N. B., Dogan, N., 2010. The impact of oil price shocks on the economic growth of selected MENA countries. Energy Journal 31, 149-176.

Besley, T., Kudamatsu, M., 2006. Health and democracy. American Economic Review 96, 313-318.

Brown, D., Hunter, W., 2004. Democracy and human capital formation: education spending in Latin America, 1980-1997. Comparative Political Studies 37, 842-864.

Brown, D., Hunter, W., 1999. Democracy and social spending in Latin America. American Political Science Review 93, 779-90.

CBI, 2014. Annual National Accounts of Iran. Central bank of Iran.

Clements, M. P., Hendry, D.F., 1995. Forecasting in cointegrated systems. Journal of Applied Econometrics 10, 127-146.

Dickey, D. A., Fuller, W. A., 1979. Distribution of the estimators for autoregressive time series with a unit root. Journal of the American Statistical Association 74, 427-431.

Dizaji, S. F, van Bergeijk, P. AG , 2013. Potential early phase success and ultimate failure of economic sanctions: A VAR approach with an application to Iran. Journal of Peace Research 50, 721-736.

Doan, T., 2000. RATS version 5 User's Guide. Estima, Evanston.

Engle, R. F, Yoo, B. S., 1987. Forecasting and testing in co-integrated systems. Journal of Econometrics 35, 143-159.

Farzanegan, M.R., 2011. Oil revenue shocks and government spending behavior in Iran. Energy Economics 33, 1055-1069.

Farzanegan, M.R., Markwardt, G., 2009. The effects of oil price shocks on the Iranian economy. Energy Economics 31, 134-151.

Farzanegan, M.R, Raeisian Parvari, M., 2014. Iranian-Oil-Free Zone and International Oil Prices. Energy Economics 45, 364-372.

Fuller, W. A., 1976. Introduction to Statistical Time Series. New York: Wiley.

Hamilton, J.D., 1996. This is what happened to the oil price-macroeconomy relationship. Journal of Monetary Economics 38, 215-220. 
Hausken, K., Martin, C.W., Plümper, T., 2004. Government spending and taxation in democracies and autocracies. Constitutional Political Economy 15, 239-259.

Hoffman, D. L., Rasche, R.H., 1996. Assessing forecast performance in a cointegrated system. Journal of Applied Econometrics 11, 495-517.

James P., Solberg E., Wolfson M., 1999. An identified systemic model of the democracy-peace nexus. Defense and Peace Economics 10, 1-38.

Johansen, S., Juselius, K., 1990. Maximum likelihood estimation and inference on cointegration-with applications to the demand for money. Oxford Bulletin of Economics and Statistics 52, 169-210.

Kaufman, R. R., Segura-Ubiergo, A., 2001. Globalization, domestic politics, and social spending in Latin America. World Politics 53, 553-587.

Lebovic, J.H., 2001. Spending priorities and democratic rule in Latin America. Journal of Peace Research 45, 427-452.

Marshall, M. G., Gurr, T.R., Jaggers, K.T., 2012. POLITYTM IV PROJECT: Dataset Users'. Manual Center for Systemic Peace.

Mork, K.A., 1989. Oil and the marcoeconomy when prices go up and down: an extension of Hamilton's results. The Journal of Political Economy 97, 740-744.

Mork, K.A., 1994. Business cycles and the oil market. The Energy Journal 15, 15-38 (Special Issue).

Naka, A., Tufte, D., 1997. Examining impulse response functions in cointegrated systems. Applied Economics 29, 1593-1603.

Olson, M. 1993. Dictatorship, democracy, and development. The American Political Science Review 87, 567-576.

Oneal, J.R., Russett, B. M., 1997. The classical liberals were right: democracy, interdependence and conflict, 1950-1985. International Studies Quarterly 41, 267-294

Pesaran, M. H., Shin, Y., 1998. Generalised impulse response analysis in linear multivariate models. Economics Letters 58, 17-29.

Plümper, T., Martin, C.W., 2003. Democracy, government spending, and economic growth: a political-economic explanation of the Barro-effect. Public Choice 117, 27-50.

Rodrik, D., 2007. One Economics, Many Recipes: Globalization, Institutions, and Economic Growth. Princeton University Press, Princeton NJ.

Saint-Paul, G., Verdier, T., 1993, Education, democracy and growth. Journal of Development Economics 42, 399-407.

Sims, C. A., 1980. Macroeconomics and reality. Econometrica 48, 1-48.

Sims, C. A., Stock, J., Watson, M., 1990. Inference in linear time series models with some unit roots. Econometrica 58, 113-144.

Sims, C.A., Zha, T., 1999. Error bands for impulse responses. Econometrica 67, 1113-1156. 
Stock, J. H., Watson, M., 2001. Vector autoregressions. Journal of Economic Perspectives 15, 101-115.

Tijerina-Guajardo, J. A., Pagán, J.A., 2003. Government spending, taxation, and oil revenues in Mexico. Review of Development Economics 7, 152-164.

Vanhanen, T., 2011. Measures of Democracy 1810-2010. FSD1289, version 5.0. Tampere: Finnish Social Science Data Archive.

Wintrobe, R., 2001. How to understand, and deal with dictatorship: an economist's view. Economics of Governance 2, 35-58.

Wintrobe, R., 2012. Autocracy and coups d'état'. Public Choice 152, 115-130.

Yildirim, J., Sezgin, S., 2005. Democracy and military expenditure: a cross-country evidence. Transition Studies Review 12, 93-100. 
Appendix A. Summary Statistics- sample period: 1960-2006

\begin{tabular}{|c|c|c|c|c|c|}
\hline 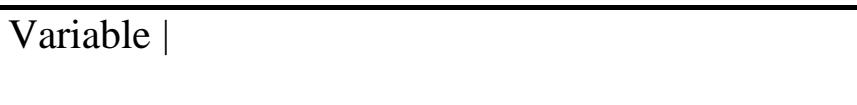 & $\overline{\mathrm{O} \text { Obs }}$ & Mean & $\begin{array}{l}\text { Std. } \\
\text { Dev. }\end{array}$ & Min & $\overline{\mathrm{Max}}$ \\
\hline $\begin{array}{l}\text { ldefetot (log of Military expenditures / total } \\
\text { expenditures) }\end{array}$ & 47 & 3.38 & 0.33 & 2.64 & 3.84 \\
\hline $\begin{array}{l}\text { ldiciptot (log of public order and disciplinary } \\
\text { expenditures/ total expenditures) }\end{array}$ & 47 & 1.84 & 0.36 & 1.30 & 2.48 \\
\hline $\begin{array}{l}\text { ledutot (log of education expenditures/total } \\
\text { expenditures) }\end{array}$ & 47 & 2.90 & 0.28 & 2.22 & 3.31 \\
\hline $\begin{array}{l}\text { lhelthtot (log of health and medical services } \\
\text { expenditures/total expenditures) }\end{array}$ & 47 & 1.60 & 0.29 & 1.02 & 2.16 \\
\hline $\begin{array}{l}\text { lculttot (log of cultural and recreational services } \\
\text { /total expenditures) }\end{array}$ & 47 & 0.61 & 0.29 & 0.13 & 1.14 \\
\hline ldefegdp (log of Military expenditures / GDP) & 47 & 1.45 & 0.53 & 0.72 & 2.31 \\
\hline $\begin{array}{l}\text { ldicipgdp (log of public order and disciplinary } \\
\text { expenditures/ GDP) }\end{array}$ & 47 & -0.09 & 0.41 & -0.76 & 0.96 \\
\hline ledugdp (log of education expenditures/GDP) & 47 & 0.97 & 0.37 & 0.29 & 1.78 \\
\hline $\begin{array}{l}\text { lhelthgdp (log of health and medical services } \\
\text { expenditures/GDP) }\end{array}$ & 47 & -0.33 & 0.54 & -1.32 & 0.57 \\
\hline $\begin{array}{l}\text { lcultgdp (log of cultural and recreational services } \\
\text { /GDP) }\end{array}$ & 47 & -1.32 & 0.45 & -2.33 & -0.61 \\
\hline ldefecap (log of Military expenditures per capita) & 46 & 2.95 & 0.71 & 1.58 & 4.25 \\
\hline $\begin{array}{l}\text { ldicipcap (log of public order and disciplinary } \\
\text { expenditures per capita) }\end{array}$ & 46 & 1.40 & 0.48 & 0.70 & 2.51 \\
\hline leducap (log of education expenditures per capita) & 46 & 2.47 & 0.51 & 1.29 & 3.34 \\
\hline $\begin{array}{l}\text { lhelthcap (log of health and medical services } \\
\text { expenditures per capita) }\end{array}$ & 46 & 1.18 & 0.68 & -0.46 & 2.13 \\
\hline $\begin{array}{l}\text { lcultcap (log of cultural and recreational services } \\
\text { per capita) }\end{array}$ & 46 & 0.19 & 0.68 & -1.39 & 1.34 \\
\hline polity index & 47 & -6.02 & 4.49 & -10.00 & 3.00 \\
\hline$V I$ (Vanhanen index of democracy) & 47 & 1.87 & 1.79 & 0.00 & 6.10 \\
\hline
\end{tabular}




\section{Appendix B. Summary of main impulse response analyses}

\begin{tabular}{|c|c|c|c|c|c|c|c|}
\hline \multirow{2}{*}{$\begin{array}{c}\text { Shock } \\
\text { variable }\end{array}$} & \multirow[t]{2}{*}{ Method } & \multirow[t]{2}{*}{ Specification } & \multicolumn{5}{|c|}{ Response (spending) variables } \\
\hline & & & Disciplinary & Health & Education & Military & Cultural \\
\hline Polity & IRF & $\begin{array}{l}\% \text { of total } \\
\text { government } \\
\text { spending }\end{array}$ & positive & positive & positive & negative & insignificant \\
\hline Polity & GIR & $\begin{array}{l}\% \text { of total } \\
\text { government } \\
\text { spending }\end{array}$ & positive & positive & positive & negative & insignificant \\
\hline VI & IRF & $\begin{array}{l}\% \text { of total } \\
\text { government } \\
\text { spending }\end{array}$ & positive & insignificant & positive & insignificant & insignificant \\
\hline MVI+ & IRF & $\begin{array}{l}\% \text { of total } \\
\text { government } \\
\text { spending }\end{array}$ & positive & insignificant & positive & negative & insignificant \\
\hline MVI- & IRF & $\begin{array}{l}\% \text { of total } \\
\text { government } \\
\text { spending }\end{array}$ & negative & negative & negative & positive & insignificant \\
\hline $\mathrm{HIV}+$ & IRF & $\begin{array}{l}\% \text { of total } \\
\text { government } \\
\text { spending }\end{array}$ & positive & insignificant & positive & negative & insignificant \\
\hline HIV- & IRF & $\begin{array}{l}\% \text { of total } \\
\text { government } \\
\text { spending }\end{array}$ & negative & insignificant & negative & insignificant & negative \\
\hline Polity & IRF & $\%$ of GDP & positive & insignificant & positive & negative & insignificant \\
\hline Polity & IRF & Per capita & insignificant & insignificant & insignificant & negative & insignificant \\
\hline
\end{tabular}

Note: The table only reports the sign of the significant responses within 2, 3 or 4 years after the initial shocks. * VI represents the Vanhanen index.* MIV+ and MIV- represent the positive and negative changes of Vanhanen index according to Mork's definition. *HIV+ and HIVrepresent the positive and negative changes of Vanhanen index according to Hamilton's definition. 


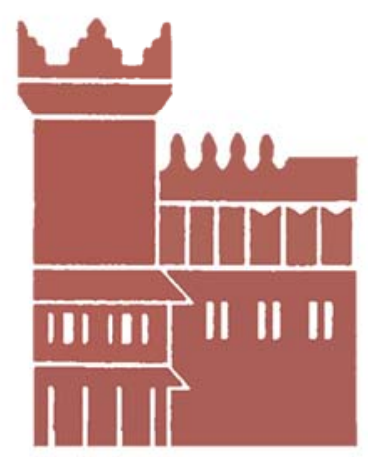

Alma Mater Studiorum - Università di Bologna DEPARTMENT OF ECONOMICS

Strada Maggiore 45

40125 Bologna - Italy

Tel. +39051 2092604

Fax +390512092664

http://www.dse.unibo.it 